\title{
Retraction Note to: Wetlands and Lakes of the World: Devashish Kar
}

Springer India 2013, xxxv + 687 p, ISBN: 978-81-322-1022-1; ISBN: 978-81-322-1023-8 (eBook), doi:10.1007/978-81-322-1023-8

\section{Gautam Aditya ${ }^{1}$}

Published online: 2 July 2018

(C) Zoological Society, Kolkata, India 2018

Retraction note: Proc Zool Soc (2017) 70:207-208

DOI 10.1007/s12595-017-0248-5

This article (Aditya, 2017) has been retracted by the author because the book which is the subject of this review was retracted in 2015.

The original article can be found online at https://doi.org/10.1007/s12595-017-0248-5.

\section{Gautam Aditya}

gazoo@caluniv.ac.in

1 Department of Zoology, University of Calcutta, Kolkata, India 